\title{
The Theory of the Firm and Its Critics: A Stocktaking and Assessment
}

\author{
Nicolai J. Foss \\ Center for Knowledge Governance \\ Department of Management, Politics, and Philosophy \\ Copenhagen Business School \\ Blaagaardsgade 23B; \\ 2200 Copenhagen N; Denmark \\ njf.lpf@cbs.dk \\ Peter G. Klein \\ Contracting and Organizations Research Institute \\ University of Missouri \\ 135 Mumford Hall \\ Columbia, MO 65211 USA \\ kleinp@missouri.edu
}

This version: August 22, 2005

Prepared for Jean-Michel Glachant and Eric Brousseau, eds.

New Institutional Economics: A Textbook, Cambridge: Cambridge University Press.

\begin{abstract}
Since its emergence in the 1970s the modern economic or Coasian theory of the firm has been discussed and challenged by sociologists, heterodox economists, management scholars, and other critics. This chapter reviews and assesses these critiques, focusing on behavioral issues (bounded rationality and motivation), process (including path dependence and the selection argument), entrepreneurship, and the challenge from knowledge-based theories of the firm.
\end{abstract}

JEL codes: B4, D23, L14, L22

Thanks to Harvey James, Martin Krause, and an anonymous reviewer for helpful comments. 


\section{Introduction}

Since it emerged in the early 1970s the new institutional economics has been the subject of intense debate. As an important part of the new institutional economics, the modern theory of the firm - mainly transaction cost economics (TCE) and property rights theory, but also agency theory and team theory - is no exception. ${ }^{1}$ Much of the debate on the theory of the firm has been "internal," in the sense that it has been conducted between scholars generally sympathetic to the new institutional approach (e.g., Hart 1995; Kreps 1996; Maskin and Tirole 1999; Brousseau and Fares 2000; Foss and Foss 2001; Furubotn 2002; MacLeod 2002).

However, there also exists a substantial, though somewhat amorphous, set of "external” critiques, arising from sociologists, heterodox economists (“old” institutionalist, Austrian, and evolutionary), and management scholars, mainly in the organization and strategy fields. Williamson’s transaction cost economics has been a favorite Prügelknabe for about three decades (e.g., Richardson 1972; Hodgson 1989; Perrow 2002), but agency theory has also drawn a fair amount of fire (Donaldson 1996). For instance, early critics argued that transaction cost economics ignored the role of differential capabilities in structuring economic organization (Richardson 1972); neglected power relations (Perrow 1986), trust, and other forms of social embeddedness (Granovetter 1985); and overlooked evolutionary considerations, including Knightian uncertainty and market processes (Langlois 1984). Such critiques have been echoed and refined in numerous contributions, and criticizing the new institutional economics remains a thriving industry. The incumbents are mainly sociologists (Freeland 2002; Buskens et al. 2003; Lindenberg 2003) and non-mainstream economists (Hodgson 1998; Loasby 1999; Witt 1999; Dosi and Marengo 2000), but new entrants are increasingly recruited from the ranks of management scholars (Pfeffer 1994), particularly from the strategic management field (Kogut and Zander, 1992; Conner and Prahalad 1996; Ghoshal and Moran, 1996; Madhok 1996).

This chapter offers an idiosyncratic review and assessment of this critical literature. ${ }^{2}$ Our assessment aims to be constructive, in that we ask if the critiques can advance the modern economic theory of the firm by identifying weak points, suggesting improvements, and the like. We

\footnotetext{
${ }^{1}$ We ignore here the claim that agency theory and property rights theory should not properly be included in the new institutional economics (Brousseau and Fares 2000).

${ }^{2}$ Some of these criticisms echo even older critiques of the neoclassical theory of the firm by Papandreou, Lester, Cyert, March, Simon and others. See Foss (2000) for brief discussions of these.
} 
do not claim to be comprehensive; unavoidably many authors, papers, and insights must be left out. However, we aim to capture what we see as the fundamental critiques.

We begin with a brief summary of core ideas in the modern economic theory of the firm, highlighting the key assumptions at which the critics have concentrated their fire. We turn next to the substance of these critiques, focusing on cognitive and behavioral issues, firm heterogeneity and production costs, and market characteristics such as path dependence, the survivor principle, and other evolutionary issues. As we consider each challenge, we discuss its implications for theoretical and applied research on the firm. In other words, we ask what, if anything, each critique suggests about how to address the three key explananda of the theory of the firm: existence, boundaries, and internal organization.

\section{The Coasian Theory of the Firm}

\section{Coase and Later Work on the Theory of the Firm}

The basic features of the emergence of the theory of the firm are well-known. As the story is normally told, the theory of the firm traces its existence back to Coase's landmark 1937 article, "The Nature of the Firm," with its key conjecture that the main explananda of the theory of the firm (existence, boundaries, and internal organization) can be explained by incorporating the “costs of using the price mechanism” into standard economic analysis. For various reasons, Coase's seminal analysis was neglected for more than three decades; the analysis was known, but not used, as Coase (1972: 68) himself has noted. However, about the same time as Coase’s lamentation, serious work on the theory of firm began to emerge, with four seminal contributions defining the central streams of research in the theory of the firm, namely transaction costs economics (Williamson 1971), the property rights or nexus-of-contracts approach (Alchian and Demsetz 1972), agency theory (Ross 1973), and team theory (Marschak and Radner 1972).

Of these four approaches, only the transaction costs approach and the property rights approach are conventionally considered theories of the firm in the strict sense. Neither team theory nor principal-agent theory explains the boundaries of the firm, de-fined in terms of asset ownership (Hart, 1995). Such an explanation must presuppose that contracts are incomplete; otherwise, everything can be stipulated contractually and there is no need for ownership, the "residual right" to make decisions under conditions not specified by contract. Transaction cost economics and property rights theory, by contrast, assume that contracts are incomplete, meaning that some con- 
tingencies or out-comes are not specified in the contract. Accordingly, our main emphasis will be on the latter two approaches. ${ }^{3}$

\section{A Simple Representation}

The basic incomplete contracting argument is illustrated by the strategic-form games shown in Figure 1. We choose this representation not for its own sake, but rather because it brings out many of the crucial underlying assumptions in the modern theory of the firm

\section{Figure 1}

\section{Game 1}

B

$$
\text { left right }
$$

up $\quad 2,2 \quad 0,0$

A

down
0,0

\section{Game 2}

B

left right

up $\quad 2,2 \quad 0,0$

A

down $\quad 0,0 \quad 4-\mathrm{u}, 1+\mathrm{u}$

Following Hurwicz (1972), one can imagine economic agents choosing game forms, and the resulting equilibria, for regulating their trade. Efficiency requires that agents choose the game form and equilibrium that maximizes the gains from trade. The two players begin by confronting Game 1. The problem here, of course, is that the Pareto criterion is too weak to select a unique equilibrium, since both $\{$ up, left and $\{$ down, right are Pareto efficient. However, the \{down, right \} equilibrium has a higher joint surplus than the \{up, left \} equilibrium, so that it will be in A's interest to bribe B to play \{right . Given complete contracting, as in agency theory, $u$, the side payment, can be chosen $(1<\mathrm{u}<2)$ to implement the equilibrium in which A plays \{down and B plays \{right . But under incomplete contracting, side payments may not be sustainable in equilibrium. ${ }^{4}$

\footnotetext{
${ }^{3}$ For expository reasons, we generally suppress the differences between the Williamson's and Hart's versions of the incomplete-contracting story. Brousseau and Fares (2000) analyze the differences in detail.

${ }^{4}$ For example, if A gives B the bribe before the game begins, B will not play \{right\}, which means that A will decide not to give B any bribe. Or, A may promise B to pay the bribe after game, but B will realize that this will not be in A's interest, and will still play \{left $\}$.
} 
The inefficiency may be remedied by contract; for example, A may agree to pay a penalty to $\mathrm{B}$ if he does not pay u, or B may agree to pay a penalty to A if he does not play \{right after receiving u. However, such contracts may not always be feasible. Contracts cannot completely safeguard against the reduction of surplus or loss of welfare stemming from incentive conflicts (given risk preferences). The analytical enterprise is therefore one of comparing alternative contracting arrangements, all of them imperfect. For example, one may compare Nash equilibria that result from different distributions of bargaining power (for example, as given by ownership patterns) (Hart 1995).

\section{Basic Characteristics of the Modern Theory of the Firm}

The above strategic-form representation helps illustrate several crucial underlying assumptions of the modern theory of the firm:

Cognition. Particularly in its formal versions, the theory of the firm follows neoclassical economics in making strong assumptions about the cognitive powers of agents. This reflects the dependence of the modern theory of the firm on mainstream information economics and game theory. While bounded rationality is invoked by some writers (particularly Williamson 1985, 1996), virtually all the contracting problems studied in the modern theory of the firm can be modeled using the more tractable notion of asymmetric information (Hart 1990). Moreover, the Bayesian notion of uncertainty underlying game-theoretic models of contracting leaves no room for "Knightian," “deep," or "radical” uncertainty. In the above representation, players can thus never experience genuine surprise.

Everything is given. Because of strong assumptions about agents' cognitive powers, modern theories of the firm portray decision situations as always unambiguous and "given.” The choice of efficient economic organization is portrayed as a standard maximization problem, as in contract design, or as a choice among given "discrete, structural alternatives" (Williamson 1996), as in the choice of governance structure. There is no learning, no need for entrepreneurial creation or discovery, and explicit room for the emergence of new contractual or organizational forms. In the representation above, the strategy spaces are fully specified ex ante.

Motivation. In the modern theory of the firm motivation is assumed to be wholly extrinsic (Frey 1997). Stronger monetary incentives always call forth more effort (in a least a particular 
dimension). Low-powered incentives play a role only in multi-task agency problem (Holmström and Milgrom 1991).

Explaining economic organization. Problems of economic organization may be represented as games where the Nash equilibrium is not Pareto optimal. While this includes some coordination games, such as the stag-hunt game (Camerer and Knez 1996), the modern theory of the firm generally disregards coordination problems. The focus is on aligning incentives, rather than coordinating actions. The function of contracts, hierarchies, reputation, and the like is to give agents incentives to choose the strategies that result in a Pareto-superior equilibrium. Transaction costs, and not production costs, are seen as the main obstacles to achieving first-best outcomes.

Methodological individualism. Aggregates play no independent role in explaining economic organization. The aim is to explain contractual and organizational form in terms of individual actions. Thus, aggregate constructs such as trust, embeddedness, organizational cognition, and capabilities are not considered part of the explanans of the modern theory of the firm; moreover, they are only seldom treated as explanandum phenomena (an exception is Kreps, 1990, on corporate culture).

Mode of explanation. As a first approximation, efficient economic organization is supposed to be consciously chosen by well-informed, rational agents. If pressed on the issue, economists of organization may also invoke evolutionary processes that are assumed to perform a sorting between organizational forms in favor of the efficient ones (Williamson 1985). Thus, explanation is either fully “intentional” or “functional-evolutionary” (Elster 1983; Dow 1987).

\section{What Are the Critics Criticizing?}

Most of the above characteristics are not particular to the economic theory of the firm; they also describe any part of game-theoretic microeconomics. Critics of the theory of the firm may thus appear simply to be criticizing modern microeconomics more generally. However, while this may indeed be the case for some critics, a different interpretation is possible: The critics are protesting the application of concepts designed for analysis of market exchange to the study of firm organization. While some economists maintain that there is no real difference between firms and markets (Alchian and Demsetz 1972; Cheung 1983), and most economists would agree that the same analytical tools are applicable to firms as well as to markets, the critics seem to argue 
that firms are essentially different from markets; many of the critics (particularly sociologists) argue that firms need to be studied using different tools (Freeland 2002).

Thus, while some critics may balk at methodological individualism and assumptions of full, instrumental rationality in general, they are likely to find such assumptions particularly objectionable when they are applied to the theory of the firm. In the literature that criticizes the modern theory of the firm firms are often portrayed in rosy terms as "mini-societies” (Freeland 2002) that provide “identity” (Kogut and Zander 1996), "higher-order organizing principles” (Kogut and Zander 1992), trust relations (Ghoshal and Moran 1996), and collective learning (Hodgson 1998) that, purportedly, "atomistic” markets cannot provide. Firms exist because and to the extent that they can supply “identity," “collective learning,” etc.

While we are skeptical of such arguments, we acknowledge that they may point to unresolved issues and weak spots in the modern theory of the firm. For example, one can reject methodological holism and still hold that there are firm-specific cultures and capabilities, the understanding of which is inadequate in the modern theory of the firm (in spite of the efforts of, e.g., Kreps 1990). Or one can argue that there is too little room for bounded rationality in this body of

theory. In the following sections, we discuss and assess a number of such critiques of the modern theory of the firm in greater detail.

\section{Cognitive and Motivational Issues}

\section{Bounded Rationality}

Formal, mainstream economics typically assumes that agents hold the same, correct model of the world and that model does not change. The theory of the firm is no exception. More precisely, these assumptions are built into formal contract theory through the assumption that payoffs, strategies, and the like are common knowledge. These assumptions are clearly at variance with the notion of bounded rationality (Simon 1955). Indeed, the game-theoretic models used in most theoretical research on the theory of the firm ignore bounded rationality altogether, although it may play a role in the "rhetorical” motivation of such research (see Foss 2003).

In contrast, bounded rationality is often invoked in Oliver Williamson's $(1985,1996)$ less formal work. "But for bounded rationality,” he argues (1996: 36), “all issues of organization collapse in favor of comprehensive contracting of either Arrow-Debreu or mechanism design kinds.” What Williamson calls “comprehensive contracting” does not allow for "governance 
structures" in the sense of mechanisms that handle the coordination and incentive problems produced by unanticipated change (Williamson 1996: chapter 4). However, the role of bounded rationality in Williamson's work is mainly to provide a reason why contracts are incomplete. ${ }^{5}$ It is a sort of background assumption that while necessary, never really assumes a central role. Indeed, many critics have observed that to the extent that bounded rationality enters the theory of the firm, it is in rather "thin” forms (e.g., Macleod 2000; Foss 2003). The reason is presumably that the theory is taken up with comparative institutional exercises, focusing on transaction cost economizing, and hence has no room for the process aspects introduced by more substantive notions of bounded rationality (e.g., Furubotn 2002).

Still, even the rather limited use of bounded rationality in the theory of the firm has been criticized. Hart (1990) argues that bounded rationality may not be necessary at all, because asymmetric information (in the form of imperfect verifiability) can do the job that bounded rationality is supposed to do, and can do so more elegantly and more consistently with mainstream modeling (see also Posner, 1993). From a different position, Dow (1987) argues that it is inconsistent to invoke bounded rationality as a necessary assumption in the analysis of contracts and governance structures, and then assume that substantively rational choices can be made with respect to the contracts and governance structures (that are imperfect because of bounded rationality). This point is echoed in Kreps's (1996) critique of contract theory. Contract theory assumes that although the parties to a contract cannot describe the benefits from an exchange relationship, they can perfectly anticipate the benefits produced by the different contractual arrangements that can structure such a relationship. Of course, this assumption is made to rationalize the ex ante choice of ownership or incentive structures. While it may make formal sense (cf. Maskin and Tirole 1999), “not everything that is logically consistent is credulous,” as Kreps (1996: 565) laconically observes in a comment on Maskin and Tirole. He argues that the Maskin and Tirole argument (and virtually all of contract theory) simply takes rationality too far, and that more attention should be paid to bounded rationality. ${ }^{6}$

\footnotetext{
${ }^{5}$ Therefore, Williamson's treatment of bounded rationality seldom goes beyond quoting Simon's dictum that man is “intendedly rational, but limitedly so." He notes that “[e]conomizing on bounded rationality takes two forms. One concerns decision processes and the other involves governance structures. The use of heuristic problem-solving ... is a decision process response” (Williamson 1985: 46). The latter "form” is not central, however, in transaction cost economics, which "is principally concerned ... with he economizing consequences of assigning transactions to governance structures in a discriminating way.”

${ }^{6}$ A perhaps deeper problem stems from trying to combine substantive rationality with respect to some variables with rationality about other variables that is very bounded indeed. This is problematic, because in reality knowledge of
} 
In contrast, bounded rationality has long been a central assumption in organization theory (e.g., March and Simon 1958; Cyert and March 1963). In fact, recent critics of the theory of the firm have drawn explicitly on these older sources to develop alternative, evolutionary views emphasizing the role of bounded rationality in problem-solving, and the role of firms as cognitive structures around such problem-solving efforts (e.g., Dosi and Marengo 1994). Other critics, also echoing behaviorist organization theory, argue that a key characteristic of firms is that they tend to shape employee cognition (Kogut and Zander 1996; Hodgson 1998; Witt 1999). For example, starting with social learning theory, Witt (1999) argues that individual cognitive frames are socially shaped and that firms can accomplish such shaping. In particular, entrepreneurs form business conceptions that underlie their "cognitive leadership," making employees internalize and collectively share the cognitive categories embodied in the business conception.

\section{Motivation}

While the role of bounded rationality in the theory of the firm has given rise to a fair amount of debate, it is nothing compared to the enormous amount of critical writings on the motivational assumptions. Opportunism in particular seems to be the favorite bête-noire. The critique of opportunism takes various forms. Empirically, the relevance of opportunism is dismissed by pointing to difficulty in observing it, for instance in industrial networks or in long-term associations between firms and their suppliers (see, e.g., Håkansson and Snehota 1990). The obvious problem with such arguments is that they misunderstand the counterfactual nature of reasoning in the theory of the firm: Opportunistic behavior is seldom observed because governance structures are chosen to mitigate opportunism. Another claim is that opportunism is not a necessary assumption in the theory of the firm (e.g., Kogut and Zander 1992), but this line of reasoning fails to provide convincing alternative accounts.

According to a more recent and more sophisticated set of arguments, the primary problem with the treatment of motivation in the theory of the firm is not opportunism per se, but rather that modern economic approaches assume that all motivation is of the "extrinsic" type (Ghoshal and Moran 1996; Osterloh and Frey 2000). In other words, all behavior is understood in terms of encouragement from an external force, such as the expectance of a monetary reward. (In contrast, when "intrinsically" motivated, individuals wish to undertake a task for its own sake). 
These arguments do not necessarily deny the reality of opportunism, moral hazard, and so on; they assert instead that there are other, better ways of handling these problems besides providing monetary incentives, sanctions, and monitoring. The arguments are often based on social psychology (notably Deci and Ryan 1985) and on experimental economics (e.g., Fehr and Gächter 2000).

In one version of the argument, Pfeffer (1994) and Ghoshal and Moran (1996) argue that the theory of the firm misconstrues the causal relation between motivation (e.g., the tendency to shirk) and the surrounding environment (the type of governance structure in place). For example, Ghoshal and Moran (1996: 21) claim that individuals within an organization perform not according to the incentives and opportunities offered, but to their "feelings for the entity." "Hierarchical" controls, they state, reduce organizational loyalty and thus increase shirking. Reliance on internal governance in the presence of relationship-specific investments, they hold, causes the very problems it is designed to alleviate: Williamson's approach becomes a "self-fulfilling prophecy," and is therefore "bad for practice." In another version of the argument Osterloh and Frey (2000) ask which organizational forms are conducive to knowledge creation and transfer. They note that elements of market control (e.g., high-powered incentives) are often introduced in firms to accomplish this. However, Osterloh and Frey argue that this only works to the extent that there is no "motivation crowding-out effect," in which extrinsic motivation does not crowd out intrinsic motivation. They draw on Deci and Ryan (1985) and other contributions to social psychology to argue that motivation may be harmed when agents perceive that their actions are subject to external control (as with a performance-pay system). Osterloh and Frey argue that forms of internal organization that foster intrinsic motivation can more successfully create and transfer tacit knowledge because such activities cannot be compelled, only enabled.

\section{Challenges to the Theory of the Firm?}

Few economists of organization have reacted to the above critiques. We suspect this is partly because taking these critiques seriously means questioning fundamental tenets of mainstream

\footnotetext{
${ }^{7}$ However, while Ghoshal and Moran question the substantial empirical literature supporting Williamson's theory, they offer little systematic evidence for their own view. They simply assert that the strong empirical relationship between specific assets and vertical integration exists because these assets reduce the cost of internal organization, independent of their effects on the hazards of market governance. They cite Masten, Meehan, and Snyder (1991), who have shown that this is a possibility with respect to specific human capital. However, there is no evidence that specific physical assets reduce the costs of internal organization, nor do Ghoshal and Moran supply a coherent theory for such an effect.
} 
economic modeling. For example, taking bounded rationality seriously opens up a Pandora’s box because bounded rationality challenges the game-theoretic foundations underlying the formal literature on the theory of the firm (subjective expected utility theory, the independence of payoff utilities, the irrelevance of labeling, and common prior beliefs (Camerer 1998)). Organizational economists may also question what bounded rationality adds to the theory (Hart 1990). Williamson (1999: 12) notes that "organization can and should be regarded as an instrument for utilizing varying cognitive and behavioral propensities to best advantage,” and that the many ramifications of bounded rationality should be explored to help identify those regularities in decisionmaking that differ from the classical von Neumann-Morgenstern-Savage model. The implications of these regularities for efficient organization can then be developed and incorporated into the theory of the firm (Williamson 1999: 18). However, Williamson (1999) mainly emphasizes that the findings of cognitive psychology are consistent with " $[t]$ he transaction cost economics triple for describing human actors - bounded rationality, farsighted contracting, and opportunism.” Moreover, many bounds on rationality are substantially mitigated by organization, because organization has recourse to specialization, which allows for economizing with cognitive effort. Such arguments cast doubt on the belief that taking bounded rationality more seriously will yield theoretical advances.

However, a handful of contributions, mainly to contract theory, do try to model agents that are boundedly rational in a more substantive sense. For example, Mookerjee (1998) shows how ambiguity may lead to incomplete contracting; Carmichael and MacLeod (2003) show that if boundedly rational agents care about sunk costs, the hold-up problem may be solved. There are various problems with such approaches. Notably, there may be too many “degrees of freedom," in the sense that virtually any cognitive bias may be thrown into a standard contracting model, thus producing a nonstandard result. Moreover, how does the theorist decide which manifestation of bounded rationality to model? The danger is that one ends up with a string of unconnected and extreme partial models with no apparent connection to empirical reality.

In our opinion, working with alternative motivational assumptions may be a more fruitful way forward. It is easier to doctor utility functions than cognitive assumptions. There is established social psychology work, the insights of which may be fed relatively directly into modeling efforts (and see Benabou and Tirole 2003). Moreover, the implications for economic organiza- 
tion may also seem more immediate (see Lazear 1991; Fehr and Gächter 2000 for concrete examples).

\section{Firm Heterogeneity, Capabilities, and Production Costs}

\section{The Knowledge-Based View}

A growing number of writers within heterodox economics (particularly evolutionary economics) and strategic management now embrace “capabilities,” “dynamic capabilities,” or “competence” approaches (e.g., Winter 1988; Langlois 1992; Kogut and Zander 1992; Foss 1993; Dosi and Marengo 1994; Teece and Pisano 1994; Langlois and Robertson 1995; Loasby 1999). We here lump all these together under the heading "knowledge-based view of the firm." Contributions to the knowledge-based view are usually launched on a background of critique of new institutional economics, particularly Williamson's version of TCE. The critique concerns the reliance on opportunism and the neglect of differential capabilities (i.e., firm heterogeneity) and dynamics (e.g., Winter 1988; Langlois 1992; Kogut and Zander 1992).

In contrast, contributors to the knowledge-based view typically begin from the empirical generalization that firm-specific knowledge is sticky and tacit and develops through pathdependent processes. This implies that organizations are necessarily limited in what they know how to do well. ${ }^{8}$ Differential capabilities imply differences in terms of the efficiency with which resources are deployed. Superior capabilities, if hard to imitate, can generate long-lived rents (Lippman and Rumelt 1982; Wernerfelt 1984; Barney 1991; Peteraf 1993). Beginning perhaps with Kogut and Zander (1992) and Langlois (1992), adherents of the knowledge-based view have also argued that the characteristics of capabilities that make them relevant to the study of competitive advantage are also crucial for the study of the main issues in economic organization. Thus, knowledge-based writers argue that a theory of the firm should be based on considerations of knowledge, rather than incentives, opportunism, and transaction costs.

\section{The Knowledge-Based View as a Theory of Economic Organization}

The idea that knowledge matters for economic organization is hardly new. George B. Richardson (1972) suggested that we begin, not from the Coasian idea of transaction costs, but

\footnotetext{
${ }^{8}$ Large parts of the knowledge-based view implicitly and sometimes explicitly subscribe to methodological collectivism (e.g., Kogut and Zander 1992; Hodgson 1998).
} 
from the idea that production can be broken down into activities underpinned by firm-specific capabilities. Some activities are similar, in that they draw on the same general capabilities; activities can be complementary, in that they are connected in the chain of production; and similarity and complementarity may obtain to varying degrees. The main point in Richardson (1972) is that the boundaries of the firm are strongly influenced by these dimensions of activities. ${ }^{9}$ However, it is unclear in Richardson's paper how exactly capabilities are supposed to influence economic organization.

Some papers (e.g., Kogut and Zander 1992; Langlois 1992) argue that differential capabilities give rise to different production costs, and that such cost differentials may crucially influence the make-or-buy decision. Thus, firms may internalize activities because they can carry out these activities in a more production (not transaction) cost-efficient way than other firms are capable of. The factors that make capabilities distinctive and costly to imitate (e.g., complexity and tacitness) also make such differences in production costs long-lived. Thus, one firm's agents may literally fail to understand what another firm wants (for example, in supplier contracts) or is offering (for example, in license contracts). The costs of making contacts with potential partners, of educating potential licensees and franchisees, of teaching suppliers what it is one needs from them, etc. — what Langlois (1992) christens “dynamic transaction costs,” to distinguish them from the transaction costs usually considered in the theory of the firm-may influence where the boundaries of the firm are placed.

Knowledge-based writers also claim that the existence of the firm can be explained in knowledge terms and without invoking opportunism (Hodgson 2004). Demsetz (1988) argues that firms exist for reasons of economizing on expenditures on communicating and coordinating knowledge. Thus, the employment contract, and hierarchy more generally, may exist because it is efficient to have the less knowledgeable being directed by the more knowledgeable. A very different argument is forwarded by Kogut and Zander (1992) who argue that firms exist because they can create certain assets—such as learning capabilities or a "shared context"- that markets purportedly cannot create:

organizations are social communities in which individual and social expertise is transformed into economically useful products and services by the application of a set of

\footnotetext{
${ }^{9}$ For example, closely complementary and similar activities are best undertaken under unified governance, whereas closely complementary but dissimilar activities are normally best undertaken under some sort of hybrid arrangement (to use Williamson's (1996) terminology).
} 
higher-order organizing principles. Firms exist because they provide a social community of voluntaristic action structured by organizing principles that are not reducible to individuals (Kogut and Zander 1992: 384).

This view, they claim, “differs radically from that of the firm as a bundle of contracts that serves to allocate efficiently property rights.” Firms’ advantages over markets derive from their being able to supply “organizing principles that are not reducible to individuals” (1992: 384).

The problem with this argument is that it does sufficiently characterize firms: Markets can also cultivate learning capabilities and shared context (as in industrial districts, for instance). Moreover, embeddedness of the kind that Kogut and Zander talk about does not require firm organization: in a moral utopia, characterized by the absence of opportunistic proclivities, the gains from embeddedness could be realized over the market. Agents could simply meet under the same factory roof, own their own pieces of physical capital equipment or rent it to each other, and develop value-enhancing “organizing principles” (to use Kogut and Zander’s term) among themselves, or in other ways integrate their specialized knowledge (as a team). Firms would not be necessary. ${ }^{10}$

\section{Challenges to the Theory of the Firm?}

While we are skeptical of the specific knowledge-based explanations for economic organization, we acknowledge that the knowledge-based view does point to some weak points in the theory of the firm. ${ }^{11}$ For example, differential capabilities probably do play a role in determining the boundaries of the firm (Walker and Weber 1984; Monteverde 1995; Argyes 1996). However, there are two major problems in this area that may hinder progress. The first is that the nature of the central construct (i.e., capabilities) itself is highly unclear. It is not clear how capabilities are conceptualized, dimensionalized, and measured, and it is not clear how capabilities emerge and are changed by individual action (Felin and Foss 2004). The second problem partly follows from

\footnotetext{
${ }^{10}$ Moreover, even in an opportunism-prone world, there may be much embeddedness "outside" firms, as it were, for example, in single industries, in firm networks, industrial districts, etc., depending on the presence of various control and enforcement mechanisms.

${ }^{11}$ In a recent paper, two leading theorists of the firm, Bengt Holmström and John Roberts (1998: 90) observed that "[I]nformation and knowledge are at the heart of organizational design, because they result in contractual and incentive problems that challenge both markets and firms. ... In light of this, it surprising that leading economic theories . .. have paid almost no attention to the role of organizational knowledge.” Similarly, Coase (1988: 47) has lamented that in his 1937 paper, he "did not investigate the factors that would make the costs of organizing lower for some firms than for others."
} 
the first: the mechanisms between capabilities and economic organization are unclear (Heiman and Nickerson 2002; Foss 2005).

One of the few attempts to provide such a mechanism is Langlois (1992), who gives a key role to dynamic transaction costs. In other words, economizing with costs of communication (i.e., dynamic transaction costs) is a possible determinant of the boundaries of the firm (and see Monteverde 1995 for this). More generally, the genuine challenges that the knowledge-based view represents has more probably more to do with the non-standard transaction problems relating to the exchange of knowledge than with the fuzzy notion of "firm capability." In other words, exchanging knowledge may lead to contractual frictions and hazards that do not involve opportunism and it may involve transaction costs that have nothing to do with misaligned incentives and everything to do with costly communication.

\section{Entrepreneurship}

A major problem with modern economic theories of the firm is that they ignore the entrepreneur (Furubotn 2002; Foss and Klein 2005). Thus, Furubotn (2002: 72-3) points out that "profit is always in the background of TCE analysis because it is impossible to say whether a particular action (and contractual arrangement) undertaken by the firm is desirable or not purely on the basis of the costs of transacting. ... There is reason, then, to give greater consideration to the question of how profits are generated.” And this leads to the theory of entrepreneurship. However, in the modern theory of the firm reference to entrepreneurship is passing at best. These approaches are largely static and “closed," meaning that they focus on solutions to given optimization problems. ${ }^{12}$

\section{Concepts of Entrepreneurship}

Probably the best-known concept of entrepreneurship in economics is Schumpeter's (1934) idea of the entrepreneur as innovator, who introduces "new combinations" - new products, production methods, markets, sources of supply, or industrial combinations - shaking the economy out of its previous equilibrium. Entrepreneurship can also be conceived as “alertness” to profit opportunities. While present in older notions of entrepreneurship, this concept has been elaborated most fully by

\footnotetext{
${ }^{12}$ Agency theory, for example, has generated important insights on the effects of incentives on effort and the relationship between incentive pay and risk. In explaining how a principal gets an agent to do something, however, the theory overlooks the more fundamental question of what the principal should want the agent to do, or indeed, how the principal got to be a principal in the first place.
} 
Kirzner (1973). Kirzner's formulation emphasizes the nature of competition as a discovery process: the source of entrepreneurial profit is superior foresight - the discovery of something (new products, cost-saving technology) un-known to other market participants. Success, in this view, comes not from following a well-specified maximization problem, but from having some knowledge or insight that no one else has. None of these accounts, however, links entrepreneurship closely to the theory of the firm. Small-business management is only one manifestation of entrepreneurship. Creativity, innovation, and alertness are undoubtedly important, but neither activity must take place within a firm. Charismatic leaders work with teams, but need not own physical assets, around which the boundaries of the firm are drawn.

\section{Putting Entrepreneurship into the Theory of the Firm}

Various attempts to put entrepreneurship into the theory of the firm exist (e.g., Langlois and Robertson 1995; Casson 1997). An attempt that stays relatively close to the new institutional theory of the firm is Foss and Klein (2005). They outline an alternative account of entrepreneurship as judgmental decision-making under conditions of uncertainty. Judgment refers primarily to business decision-making when the range of possible future outcomes, let alone the likelihood of individual outcomes, is generally un-known (what Knight [1921] terms uncertainty, rather than mere probabilistic risk). The concept of entrepreneurship as judgment has a direct and natural link to the theory of the firm. Because markets for judgment are closed, the exercise of judgment requires starting a firm; moreover, judgment implies asset ownership. In this approach, resource uses are not data, but are created as entrepreneurs envision new ways of using assets to produce goods. The entrepreneur's decision problem is aggravated by the fact that capital assets are heterogeneous, and it is not immediately obvious how they should be combined. Asset ownership facilitates experimenting entrepreneurship: acquiring a bundle of property rights is a low cost means of carrying out commercial ex-

perimentation. Moreover, important features of internal organization such as delegation and contractual incompleteness can be understood in terms of employers' attempts to facilitate "productive” entrepreneurship while discouraging non-productive forms of decision-making. In short, firm boundaries and internal organization may be understood as responses to entrepreneurial processes of experimentation.

\section{Challenges to the Theory of the Firm?}


Will these insights be incorporated into the economic theory of the firm? Because these concepts lie fundamentally outside the standard constrained optimization framework, they are inherently difficult to model mathematically. Modern economists have difficulty appreciating ideas that are not expressed in this familiar language. Indeed, most recent theoretical advances in the economic theory of the firm have been developed within the more formal framework associated with Grossman, Hart, and Moore (Grossman and Hart 1986; Hart and Moore 1990), not the more "open” framework associated with Williamson. ${ }^{13}$ Relaxing this constraint may lead to considerable advances in economists' understanding of the firm.

\section{Process Issues}

\section{Path Dependence}

The claim that the theory of the firm, because of its emphasis on efficiency at a point of time and on cross-sectional variation, is ahistorical and neglects process has often been made by economists and management scholars within both the knowledge-based and the evolutionary perspective. Thus, according to Winter (1988: 178):

In the evolutionary view - perhaps in contrast to the transaction cost view-the size of a large firm at a particular time is not to be understood as the solution to some organizational problem. General Motors does not sit atop the Fortune 500 ... because some set of contemporary cost minimization imperatives (technological or organizational) require a certain chunk of the U.S. economy to be organized in this manner. Its position at the top reflects the cumulative effect of a long string of happenings stretching back into the past."

One way to interpret this critique is that the theory of the firm seeks to explain the governance of individual transactions (Williamson 1996), or clusters of attributes (Holmstrom and Milgrom1994), without identifying how the governance of a particular transaction may depend on how previous transactions were governed. Argyres and Liebeskind (1999) term this historical dependency "governance inseparability." Where governance inseparability is present, firms may rely on governance structures that appear inefficient at a particular time, but which make sense as part of a longer-term process. Changes in governance structure affect not only the transaction in question, but the entire temporal sequence of transactions. This may make organizational form appear more "sticky" than it really is.

\footnotetext{
${ }^{13}$ Bajari and Tadelis (2001) is a prominent exception.
} 
This criticism will sound familiar to Austrian and evolutionary economists, who have long argued for a "process" view of economic activity that takes time seriously (Hayek 1948 Kirzner 1973; Dosi 2000). Hayek (1948) distinguished between the neoclassical economics notion of “competition," identified as a set of equilibrium conditions (number of market participants, characteristics of the product, and so on), and the older notion of competition as a rivalrous process. Practices that appear inefficient or even anticompetitive at a given moment are better understood as part a process of competition through time; it is the process that should be evaluated in welfare terms, not the conditions that obtain at a particular moment in the process

Williamson (1996), recognizing the need to incorporate history into transaction cost economics, has introduced the notion of remediableness as a welfare criterion. The outcome of a pathdependent process is suboptimal, he argues, only if it is remediable - that is, an alternative outcome can be implemented with net gains. Merely pointing to a hypothetical superior outcome, if it not attainable, does not establish suboptimality. Thus, a governance structure or contractual arrangement "for which no superior feasible alternative can be described and implemented with expected net gains is presumed to be efficient” (Williamson 1996: 7) (for a critique, see Furubotn 2002: 89-90).

\section{Selection and Survival: Are all Organizations "Efficient"?}

The explanation of economic organization in terms of efficiency has been one of the most frequently criticized characteristics of the theory of the firm: Assuming that agents can figure out the efficient organizational arrangements seems to collide with the assumption of bounded rationality (Dow 1987; Furubotn 2002). Presumably in response to this problem, early work in the theory of the firm often explicitly assumed that market forces work to cause an "efficient sort" between transactions and governance structures, an assumption that is not in general tenable.

While appealing to market selection, Williamson (1988: 174) also clearly recognizes that the process of transaction cost economizing is not automatic. Still, he maintains that the efficiency presumption is reasonable, offering the argument that inefficient governance arrangements will tend to be discovered and undone. ${ }^{14}$ Clearly, this assumption is not an innocuous one. It is in fact a key underlying assumption in virtually all empirical work in the theory of the firm. A general

\footnotetext{
${ }^{14}$ Concerning vertical integration, for example, Williamson (1985: 119-20) writes that "backward integration that lacks a transaction cost rationale or serves no strategic purposes will presumably be recognized and will be undone," adding that mistakes will be corrected more quickly "if the firm is confronted with an active rivalry."
} 
problem with the empirical literature on organizational form is that we usually observe only the business arrangements actually chosen. However, if these arrangements are presumed to be efficient, then we can draw inferences about the appropriate alignment between transactional characteristics and organizational form simply by observing what firms do. The problem is that the efficiency assumption has always been taken as an essential, but untested, background assumption.

In one of the few attempts to grapple empirically with the efficiency assumption, Lien and Klein (2004) examine the assumption that decisions or behaviors that occur frequently in a population of competitive firms are on average more efficient than those that occur rarely. They conduct the test in the context of corporate diversification. If the survivor principle holds, those pairs of industries most frequently combined within firms ("related" businesses) should tend to represent more efficient combinations than those pairs that are rarely combined. As firms strive to improve their performance, they tend to exit "unrelated" industries, that is, industries that are poor matches for their other businesses. Using detailed data on firms' business portfolios from the AGSM/Trinet database for the early 1980s, Lien and Klein (2004) show that the survivor-based measure of relatedness is a strong predictor of exit, even when controlling for other firm and industry characteristics that might affect the decision to withdraw from a particular industry. During that period, then, the competitive selection process did tend to filter out inappropriate business combinations. ${ }^{15}$

Another approach is to see if "appropriately" organized firms - that is, firms organized along the lines recommended by the theory of the firm—outperform the feasible alternatives. Several papers in the empirical TCE literature use a two-step procedure in which organizational form (in particular, the relationship between transactional characteristics and governance structure) is endogenously chosen in the first stage, then used to explain performance in the second stage. By endogenizing both organizational form and performance this approach also mitigates the selection bias associated with OLS regressions of performance on firm characteristics. ${ }^{16}$

These evolutionary approaches shed considerable light on the processes by which organizations adapt and change, along with the costs of misalignment or maladaptation. However, reli-

\footnotetext{
${ }^{15}$ However, the early 1980s was a period of corporate refocus and de-conglomeration (Bhide 1990; Shleifer and Vishny 1991) and exit decisions during this period may reflect fashion and herd behavior, not efficiency. Moreover, though the findings support using the efficiency assumption in research on diversification, it may not hold for other decisions, such as the choice between market and hierarchical governance.

${ }^{16}$ Some representative papers using a two-stage approach (such as Heckman's selection model) in this fashion are Masten, Meehan, and Snyder (1991) and Saussier (2000).
} 
ance on evolutionary models introduces additional problems. In many cases, survival may not be the best measure of performance, compared with profitability or market value. Poorly performing firms may survive due to inefficient competitors, regulatory protection, or legal barriers to exit such antitakeover amendments or an overprotective bankruptcy code. In short, efficient alignment between transactions and governance should be expected only if the selection environment is strong. Moreover, when market conditions change rapidly and unexpectedly, ex post survival may not be a good measure of ex ante efficiency; a particular organizational form may be right for the times, but the times change. Indeed, the optimal organizational forms may be those that adapt most readily to new circumstances (Boger, Hobbs, and Kerr 2001).

\section{Conclusion}

Almost two decades ago Milgrom and Roberts (1988: 450) argued that the "incentive-based transaction costs theory has been made to carry too much of the weight of explanation in the theory of organizations,” and predicted that “competing and complementary theories” would emerge, "theories that are founded on economizing on bounded rationality and that pay more attention to changing technology and to evolutionary considerations.” However, despite the importance in the management literature of knowledge-based or capabilities theories of the firm, this body of thought cannot yet be considered a serious competitor to the "incentive-based transaction costs theory." No other serious competitors have emerged.

There are many reasons for this. One possible reason is that the conventional theory of the firm is sufficiently successful, theoretically and empirically, that competitors have a hard time gaining a foothold. Still, as we have stressed throughout this chapter, many of the critiques do in fact point to weaknesses in the theory of the firm that should ideally be remedied. A further reason is that the critics tend to focus on phenomena that are difficult to model, phenomena that are not readily "tractable" in the sense familiar to mainstream economists. Innovation, entrepreneurship, bounded rationality, learning, evolutionary processes, and differential capabilities are examples of such phenomena. We should not expect to see these phenomena integrated into the mainstream economic theory of the firm until the formal tools that can handle them have been developed. Moreover, the empirical literature supporting the challenges outlined above tends to be idiosyncratic, based on experimental or qualitative work rather than the standard econometric analysis familiar to economists. Finally, the various critiques are not separate but overlapping or complementary. For example, the claim that the theory of the firm neglects bounded rationality is 
very close to the claim that it ignores differential capabilities, learning, and path dependence. In turn, the complaint that the theory of the firm neglects the latter phenomena is closely related to concerns that it assumes, uncritically, that selection forces operate to produce efficiency. In other words, the critiques come in a package, so that embracing one critique may be taken as embracing the rest — which would mean abandoning the theory of the firm as we know it.

\section{References}

Alchian, Armen A. and Harold Demsetz. 1972. "Production, Information Costs, and Economic Organization,” Amer. Econ. Rev., 62, pp. 772-795.

Argyres, Nicholas S. 1996. "Evidence on the Role of Firm Capabilities in Vertical Integration Decisions," Strat. Man. J., 17, pp. 129-50.

Argyres, Nicholas S. and Julia Porter Liebeskind. 1999. "Contractual Commitments, Bargaining Power, and Governance Inseparability: Incorporating History into Transaction Cost Theory,” Acad. Man. Rev., 24, pp. 49-63.

Bajari, Patrick, and Steven Tadelis. 2001. "Incentives versus Transactions Costs: A Theory of Procurement Contracts,” RAND J. Econ., 32, pp. 387-407.

Barney, Jay. B. 1991. “Firm Resources and Sustained Competitive Advantage.” J. Man., 17, pp. 99-120.

Benabou, Roland and Jean Tirole. 2003. “Intrinsic and Extrinsic Motivation,” Rev. Econ. Stud., 70:3, pp. 489-520.

Bhide, Amar. 1990. “Reversing Corporate Diversification,” J. Appl. Corp. Fin., 3, pp. 70-81.

Boger, Silke, Jill E. Hobbs, and William A. Kerr. 2001. "Supply Chain Relationships in the Polish Pork Sector,” Supply Chain Management, 6, pp. 74-82.

Brousseau, Eric and M’hand Fares. 2000. "Incomplete Contracts and Governance Structures: Are Incomplete Contract Theory and New Institutional Economics Substitutes or Complements?” in Institutions, Contracts and Organization: Perspectives from New Institutional Economics. Claude Ménard, ed. Cheltenham: Edward Elgar, pp. 399-421.

Buskens, Vincent, Werner Raub, and Chris Snijders, eds. 2003. The Governance of Relations in Markets and Organizations. Amsterdam: JAI Press.

Camerer, Colin and Marc Knez. 1996. "Coordination, Organizational Boundaries and Fads in Business Practice,” Ind. Corp. Change, 5, pp. 89-112.

Camerer, Colin. 1998. "Behavioral Economics and Nonrational Organizational Decision Making,” in Debating Rationality. Jennifer J. Halpern and Robert N. Stern, eds. Ithaca: Cornell University Press, pp. 53-77.

Carmichael, Lorne and W. Bentley MacLeod. 2003. "Caring About Sunk Costs: A Behavioral Solution to the Hold-up Problem,” J. Law Econ \& Org,.19, pp. 106-118.

Casson, Mark. 1997. Information and Organization. Oxford: Oxford University Press.

Cheung, Stephen N. S. 1983. “The Contractual Nature of the Firm,” J. Law Econ., 26:1, pp. 1-21.

Coase, Ronald H. 1937. “The Nature of the Firm,” Economica, N.S., 4, pp. 386-405.

Coase, Ronald H. 1972. "Industrial Organization: A Proposal for Research,” in Ronald H. Coase., The Firm, the Market, and the Law. Chicago: University of Chicago Press, 1988, pp. 57-74. 
Coase, Ronald H. 1988. The Firm, the Market and the State. Chicago: University of Chicago Press.

Conner, Kathleen R. and C.K. Prahalad. 1996. “A Ressource-based Theory of the Firm: Knowledge vs. Opportunism,” Org. Sci. 7, pp. 477-501.

Cyert, Richard M. and James G. March. 1963. A Behavioral Theory of the Firm. Englewood Cliffs: Prentice Hall.

Deci, Edward L. and Richard M. Ryan. 1985. Intrinsic Motivation and Self-Determination in Human Behavior. New York: Plenum.

Demsetz, Harold. 1988. "Profit as a Functional Return: Reconsidering Knight’s Views,” in Harold Demsetz, Ownership, Control and the Firm. The Organization of Economic Activity, vol. 1.Oxford and New York: Blackwell, pp. 236-247.

Donaldson, Lex. 1996. For Positivist Organization Theory: Proving the Hard Core. London: Sage.

Dosi, Giovanni and Luigi Marengo. 1994. "Some Elements of an Evolutionary Theory of Organizational Competences," in Evolutionary Concepts in Contemporary Economics. Richard W. Englander, ed. Ann Arbor MI: University of Michigan Press, pp. 157-178.

Dosi, Giovanni and Luigi Marengo. 2000. "On the Tangled Discourse between Transaction Cost Economics and Competence-based Views of the Firm: Some Comments," in Competence, Governance, and Entrepreneurship. Nicolai J Foss and Volker Mahnke, eds. Oxford: Oxford University Press, pp. 8092.

Dosi, Giovanni. 2000. Innovation, Organization, and Economic Dynamics: Selected Essays. Cheltenham: Edward Elgar.

Dow, Gregory K. 1987. “The Function of Authority in Transaction Cost Economics,” J. Econ. Behav. Organ., 8, pp. 13-38.

Elster, Jon. 1983 Explaining Technical Change. A Case Study in the Philosophy of Science. Cambridge: Cambidge University Press.

Fehr, Ernst and Simon Gächter. 2000. "Fairness and Retaliation: The Economics of Reciprocity.” J. Econ. Perspect., 14, pp. 159-182.

Felin, Teppo and Nicolai J. Foss. 2004. "Methodological Individualism and the Organizational Capabilities Approach.,” Working Paper 2004-5, Center for Knowledge Governance, Copenhagen Business School, http://www.cbs.dk/ckg.

Foss, Kirsten and Nicolai Foss. 2001. “Assets, Attributes and Ownership,” Int. J. Econ. Bus., 8, pp. 19-37.

Foss, Nicolai and Peter G. Klein. 2005. "Entrepreneuship and the Theory of the Firm: Any Gains From Trade?” in Handbook of Entrepreneurship: Disciplinary Perspectives. Rajshree Agarwal, Sharon A. Alvarez, and Olav Sorenson, eds. (Kluwer, forthcoming).

Foss, Nicolai J. 1993. “Theories of the Firm: Contractual and Competence Perspectives,” J. Evolutionary Econ., 3, pp. 127-144.

Foss, Nicolai J. 2000. The Theory of the Firm, Vol. I-IV. London: Routledge.

Foss, Nicolai J. 2003. "Herbert Simon’s Grand Theme in the Economics of Organization: "Much Cited and Little Used',” J. Econ. Psych., 24, pp. 245-264.

Foss, Nicolai J. 2005. Strategy and Economic Organization in the Knowledge Economy. Oxford: Oxford University Press

Freeland, Robert F. 2002. “The Firm as a Minisociety,” draft manuscript.

Frey, Bruno. 1997. Not Just for the Money: An Economic Theory of Personal Motivation. Aldershot: Edward Elgar. 
Furubotn, Eirik. 2002. “Entrepreneurship, Transaction-Cost Economics, and the Design of Contracts,” in The Economics of Contracts. Eric Brousseau and Jean-Michel Glachant, eds. Cambridge: Cambridge University Press, pp. 72-97

Ghoshal, Sumantra, and Peter Moran. 1996. "Bad for Practice: A Critique of the Transaction Cost Theory,” Acad. Man. Rev., 21, pp.13-47.

Granovetter, Mark S. 1985. "Economic Action and Social Structure: The Problem of Embeddedness”. Am. J. Soc. , 91, pp. 481-510.

Grossman, Sanford, and Oliver Hart. 1986. "The Costs and Benefits of Ownership: A Theory of Vertical Integration,” J. Polit. Economy, 94, pp. 691-719.

Håkansson, Håkan and Ivan Snehota. 1990. "No Business is an Island: The Network Concept of Business Strategy,” Scand. J. Man., 5, pp. 187-200.

Hart, Oliver. 1990. “Is ‘Bounded Rationality’ an Important Element of a Theory of Institutions?” J. Inst. Theoretical Econ., 146, pp. 696-702.

Hart, Oliver, and John Moore. 1990. "Property Rights and the Nature of the Firm,” J. Polit. Economy, 98, pp. 1119-1158.

Hart, Oliver. 1995. Firms, Contracts, and Financial Structure. Oxford: Oxford University Press.

Hayek, Friedrich A. von 1948. Individualism and Economic Order. Chicago: University of Chicago Press.

Heiman, Bruce and Jack A. Nickerson. 2002. "Towards Reconciling Transaction Cost Economics and the Knowledge-based View of the Firm: The Context of Interfirm Collaborations,” Int. J. Econ. Bus., 9, pp. 97-116.

Hodgson, Geoffrey M. 1989. Economics and Institutions: A Manifesto for a Modern Institutional Economics. Oxford: Polity Press.

Hodgson, Geoffrey M. 1998. "Competence and Contract in the Theory of the Firm,” J. Econ. Behav. Organ., 35, pp. 179-201.

Hodgson, Geoffrey M. 2004. The Evolution of Institutional Economics: Agency, Structure and Darwinism in American Institutionalism. London and New York: Routledge.

Holmström, Bengt and John Roberts. 1998. “The Boundaries of the Firm Revisited,” J. Econ. Perspect., 12, pp. 73-94.

Holmström, Bengt and Paul Milgrom. 1991. "Multitask Principal-Agent Analysis: Incentive Contracts, Asset Ownership and Job Design,” J. Law, Econ., Organ., 7, pp. 24-54.

Holmström, Bengt, and Paul Milgrom. 1994. "The Firm as an Incentive System,” Amer. Econ. Rev., 84, pp. 972-91.

Hurwicz, Leonid. 1972. “On Informationally Decentralized Systems,” in Decision and Organization. Charles B. McGuire and Roy Radner, eds. Amsterdam: North-Holland, pp. 297-336.

Kirzner, Israel M. 1973. Competition and Entrepreneurship. Chicago: University of Chicago Press.

Knight, Frank H. 1921. Risk, Uncertainty and Profit. 1964 reprint. New York: Augustus M. Kelley.

Kogut, Bruce and Udo Zander. 1992. "Knowledge of the Firm, Combinative Capabilities, and the Replication of Technology,” Org. Sci., 3, pp. 383-397.

Kogut, Bruce and Udo Zander. 1996. "What Firms Do? Coordination, Identity and Learning,” Org. Sci., 7, pp. 502-518. 
Kreps, David M. 1990. “Corporate Culture and Economic Theory,” in Perspectives on Positive Political Economy. James Alt and Kenneth Shepsle, eds.New York: Cambridge University Press.

Kreps, David M. 1996. “Markets and Hierarchies and (Mathematical) Economic Theory,” Ind. Corp. Change, 5, pp. 561-595.

Langlois, Richard N, and Paul L. Robertson. 1995. Firms, Markets, and Economic Change: A Dynamic Theory of Business Institutions. London: Routledge.

Langlois, Richard N. 1984. "Internal Organization in a Dynamic Context: Some Theoretical Considerations," in Communication and Information Economics: New Perspectives. Jussawalla M. and Helene Ebenfield, eds. Amsterdam, North-Holland, pp. 23-49.

Langlois, Richard N. 1992. “Transaction Cost Economics in Real Time,” Ind. Corp. Change, 1, pp. 99127.

Lazear, Edward P. 1991. “Labor Economics and the Psychology of Organizations,” J. Econ. Perspect., 5, pp. 89-110.

Lien, Lasse B. and Peter G. Klein. 2004. “Can the Survivor Principle Survive Diversification?” Working Paper, Norwegian School of Economics and Business Administration, http://euro.nhh.no/sol/tceworkshop/

Lindenberg, Sigward. 2003. “The Cognitive Side of Governance,” Research in the Sociology of Organizations, 20, pp. 47-76.

Lippman, Steven A. and Richard P. Rumelt. 1982. "Uncertain Imitability: an Analysis of Interfirm Differences in Efficiency under Competition.” Bell J. Econ., 13, pp. 418-438.

Loasby, Brian J. 1999. Knowledge, Institutions, and Evolution in Economics. London: Routledge.

MacLeod, William Bentley. 2000. “Complexity and Contract,” Revue Econ. Ind., 92, pp. 149-178.

MacLeod, William Bentley. 2002. “Complexity and Contract,” in The Economics of Contracts. Eric Brousseau and Jean-Michel Glachant, eds. Cambridge: Cambridge University Press, pp. 213-240.

Madhok, Anoop. 1996. "The Organization of Economic Activity: Transaction Costs, Firm Capabilities, and the Nature of Governance," Org Sci, 7, pp. 577-590.

March, James G. and Herbert A. Simon. 1958. Organizations. New York: Wiley.

Marschak, Jacob, and Roy Radner. 1972. Economic Theory of Teams. New Haven: Cowles Foundation and Yale University Press, 1972.

Maskin, Eric and Jean Tirole. 1999. “Unforeseen Contingencies and Incomplete Contracts,” Rev. Econ. Stud., 66, pp. 83-114.

Masten, Scott E., James W. Meehan, and Edward A. Snyder. 1991. “The Costs of Organization,” J. Law, Econ., Organ., 7, pp. 1-25.

Milgrom, Paul J. and John D. Roberts. 1988. "Economic Theories of the Firm: Past, Present, and Future,” Can. J. Econ., 21, pp. 444-458.

Monteverde, Kirk. 1995. “Technical Dialog as an Incentive for Vertical Integration,” Man Sci, 41, pp. 1624-38.

Mookerjee, Sujoy. 1998. “Ambiguity Aversion and Incompleteness of Contractual Form,” Amer. Econ. Rev., 88, pp. 1207-1231.

Osterloh, Margit and Bruno Frey. 2000. "Motivation, Knowledge Transfer and Organizational Form,” Org Sci, 11, pp. 538-550.

Perrow, Charles. 1986. Complex Organizations: a Critical Essay. $3^{\text {rd }}$ ed. New York: McGraw-Hill. 
Perrow, Charles. 2002. "Economic Theories of Organization,” Central Currents in Organization Theory, 4, pp. 244-271.

Peteraf, Margaret A. 1993. "The Cornerstones of Competitive Advantage: A Resource-Based View.” Strat. Man. J., 14, pp. 179-191.

Pfeffer, Jeffrey. 1994. Competitive Advantage through People: Unleashing the Power of the Work Force. Boston: Harvard Business Press.

Posner, Richard A. 1993. “The New Institutional Economics Meets Law and Economics.” J. Inst. Theoretical Econ., 149 :1, pp. 73-87.

Richardson, George B. 1972. “The Organisation of Industry,” Econ. J., 82, pp. 883-96.

Ross, Stephen A. 1973. “The Economic Theory of Agency: The Principal’s Problem,” Amer. Econ. Rev., 63, pp.134-139.

Saussier, Stéphane. 2000. "Transaction Costs and Contractual Incompleteness: The Case of Electricitie de France,” J. Econ. Behav. Organ., 42, pp. 189-206.

Schumpeter, Joseph A. 1934. The Theory of Economic Development: An Inquiry into Profits,Capital, Credit, Interest and the Business Cycle. Cambridge Mass.: Harvard University Press.

Shleifer, Andre, and Robert Vishny. 1991. “Takeovers in the '60s and '80s: Evidence and Implications,” Strat. Man.J., 12, pp. 51-59.

Simon, Herbert A. 1955, “A Behavioral Model of Rational Choice,” Quart. J. Econ., 69, pp. 99-118.

Teece, David J. and Gary Pisano. 1994. “The Dynamic Capabilities of Firms: an Introduction,” Ind. Corp. Change, 3, pp. 537-556.

Walker, Gordon, and David Weber. 1984. “A Transaction Cost Approach to Make-or-Buy Decisions,” Admin. Sci. Q., 29, pp. 373-91.

Wernerfelt, Birger. 1984. “A Resource-Based View of the Firm,” Strat. Man. J., 5, pp. 272-280.

Williamson, Oliver E. 1971. "The Vertical Integration of Production: Market Failure Considerations,” Amer. Econ. Rev., 61, pp. 112-123.

Williamson, Oliver E. 1985. The Economic Institutions of Capitalism. New York: Free Press.

Williamson, Oliver E. 1988. “Economics and Sociology,” in Industries, Firms, and Jobs. George Farkas and Paula England, eds. New York: Plenum Press, pp. 159-186.

Williamson, Oliver E. 1996. The Mechanisms of Governance. Oxford: Oxford University Press.

Williamson, Oliver E. 1999. "Human Actors and Economic Organization,” Business and Public Policy Working Paper BPP-72, Institute of Management, Innovation \& Organization, University of California, Berkeley.

Winter, Sidney G. 1988. “On Coase, Competence, and the Corporation,” J. Law, Econ, \& Org., 4, pp. 163-180.

Witt, Ulrich. 1999. "Do Entrepreneurs Need Firms? A Contribution to a Missing Chapter in Austrian Economics,” Rev. Austrian Econ., 11, pp. 99-110. 